\title{
THE ORGANISATION OF PRIMARY MEDICAL CARE IN THE ARMY
}

\author{
Colonel F. G. NEILD, M.R.C.S., L.R.C.P., D.P.H., D.I.H., Late R.A.M.C. * \\ Colonel J. G. P. POWER, M.B., M.F.C.M., D.P.H., D.I.H., D.T.M.\&H., \\ Late R.A.M.C.** \\ Lieutenant-Colonel W. R. O. EGGINGTON, \\ M.B., B.S., D.P.H., D.I.H., D.T.M.\&H., R.A.M.C. $†$ \\ Major I. P. CRAWFORD, \\ G.M., M.R.C.S., L.R.C.P., D.P.H., D.I.H., D.T.M.\&H., R.A.M.C. § \\ Army School of Health, Ash Vale
}

SUMMARY: The use of AF W 3181 in assessing minor morbidity is discussed. Recent surveys of family morbidity in B.A.O.R., Singapore and Hong Kong indicate that morbidity returns must be analysed in considerable depth to assist in the proper organisation of primary medical care.

A recent editorial in the Journal (1970) suggested that the general practitioner in the Army was probably more acutely aware than any of his medical colleagues of the increasing prevalence of psycho-social problems, since for him 'problems' rather than ' sickness' crowd his waiting room, while a letter by Cormack in a later Journal (1970) suggested that it was this very work which disenchanted the younger doctors working in isolated practices which were only loosely grouped.

In 1964 the Journal devoted a whole number to 'Group Practice' in which Dr. John Fry, the newly appointed Honorary Consultant in General Practice, took a closer look, Dr. Donald Crombie dealt with research and other authors covered the remaining aspects of general practice. Dr. Fry gave as his first priority for solving the problems facing general practice the establishment of a 'Beeching-type' analysis, setting up operational research units which would accurately pin-point the problems requiring solution. It is therefore the purpose of this paper to examine what statistical indices are now available for this assessment.

\section{Minor morbidity (monthly AF W 3181)}

Analyses of these were recorded in the Annual Report of the Health of the Army for the first time postwar in 1966 (they were always recorded prewar) and, although many medical officers feel that the information recorded is of equivocal value, it is suggested that if analysed in depth they could be of great value. The latest figures for 1970 only specify rates per thousand of broad conditions-Respiratory, Alimentary, Skin and Injuries-but, as with hospital admissions, they show what a very high figure 'All Other Diseases' represent, approximately one-third of soldiers and nearly 50 per cent in the case of womens' services.

Overall, families are not recorded but figures for B.A.O.R. and other Commands

* Now Beacon Cottage, Burys Bank Road, Greenham Common, Newbury, Berks.

** Now Chief Medical Ófficer, UNFICYP, B.F.P.O. 567.

$\dagger$ Now School of Army Health, R.A.M.C. Training Centre, Ash Vale.

+ Now D.A.D.A.H., A.M.D. 5, Lansdowne House, London. 
are available and some recent work described later has made a start into the dissecting of 'All Other Diseases' by condition, sex and age group.

AF W 3181 can also be examined at District level to ascertain the individual medical officer's work load. In 1959 an analysis was carried out of the AF W 3181 of 37 medical centres in Aldershot Garrison. This showed that there was considerable work load difference between the various types of medical centres; that of services performed (i.e. doctor/patient contacts) 40 per cent were spent in seeing the sick in the medical centre, 4.2 per cent in domiciliary visits, 18.2 per cent on PULHEEMS examinations and other inspections and 37.6 per cent on immunisation procedures and that total medical services performed daily averaged in intake units (NS) 50 and in field force units 14 , while a families medical officer made one domiciliary visit for every 2.5 patients seen. These figures indicated that a medical officer (M.O.) in medical charge of troops must spend almost as much time on immunisation procedures as seeing patients, and that in field force units M.Os must spend more than two-thirds of their working day on training their Regimental Aid Post staffs, health education and exercises.

These figures are some 10 years old and since then of course has appeared the multi-medical centre concept both static, field force and families but no figures are available, other than a work study report (1968) on the requirements for a 4 medical officer centre for field force units in Tidworth. This report based on the study of the multi-medical centre in Aldershot indicated that there was firstly a lack of any clearcut organisation and secondly an under-utilisation of resources and further that there appeared to be a number of fundamental questions that needed answers relating to the purpose, function and organisation of the R.A.M.C. providing medical support both on operations and in barracks.

In parenthesis, if our immunisation records were computerised, as had been done by some Local Health Authorities since 1962, what a heavy load could be taken off M.Os and their staffs. Other suggestions for improving the context of the general practitioner's (G.P.) work, given in the Chief Medical Officer's report for England and Wales for 1958 , were that a nurse working $2 \frac{1}{2}$ to $3 \frac{1}{2}$ hours per week per thousand patients could undertake work such as injections, dressings, urinalysis, immunisations and the taking of blood specimens on which a doctor spent 4 to 8 per cent of his time as well as widening the range of services provided. It was also found that, doctors taking part in the survey were spending up to 10 hours per week in the driving seat of their cars, so obviously if patients who cannot get to the surgery are offered transport valuable medical time is saved.

\section{Admission to medical units (monthly AF W 3166)}

As with minor morbidity the latest figures for 1970 show what a very small proportion of 'All Diseases', the more traditional ones form, in the United Kingdom (U.K.) approximately one third for soldiers and just over 20 per cent for Womens services and again there is no mention of families. However, family figures are available for Commands, less U.K. It is in fact of interest as the last complete prewar Annual Report of the Health of the Army for 1937 shows that all this information was formerly given for soldiers and families by both theatres and commands. However, immediately postwar with a sprinkling of families overseas and the thought at home that all families 
G.P. cover, post-1948, had gone to the National Health Service, this omission might have been acceptable, but in recent years there has been a tremendous change. Whereas in B.A.O.R. in 1955, 76 per cent of hospital admissions were soldiers and 24 per cent members of families, in 1963 the proportions were 48 per cent soldiers and 52 per cent families and in 1970-30 per cent and 70 per cent i.e. a complete turn in 15 years; so that inevitably the care of families is bound to make increasing demands on the Army doctor's time. From the total admissions to medical units for 1970 it will be noted that it is only in the Persian Gulf and other remote stations that soldiers form the bulk of the admissions, while even in the U.K. it is only just over 50 per cent.

It is also questionable whether admission to medical units reflects the true workload of medical units. Up to 1970 an admission was someone who had been in a medical unit for over 48 hours, yet we know a large number of people, possibly involving many specialities, may be admitted overnight for an investigation-e.g. barium enema. Secondly out-patients aren't included at all and yet varying estimates give the out-patient load as perhaps quarter to half the total workload of a hospital.

\section{The psycho-social effects of environment}

From the rates of admission by theatres the effect of an environment can be seen very clearly. For instance the further East the soldier goes the higher the venereal disease rate. From the high rate of psychiatric disease in the Persian Gulf it is apparent that he doesn't like unaccompanied service and in fact psychiatric conditions constitute the commonest cause for casevac from all theatres.

In a recent report on Army housing in the U.K.(1968) carried out in South West District, it was stated that, in Tidworth " a town without a heart" it is significant that the morbidity of neuroses among Army wives is particularly high in spite of the excellent medical service provided and the fact that the majority of families are housed in dwellings of modern construction and high standards. The report suggested therefore that whereas in the past accommodated families had been in the minority and planning has been orientated to military requirements and satisfying the needs of men in barracks, the situation has now reversed with an overall entitlement of 50 per cent married accommodation and an average family size of husband, wife and 2 children, making the proportion of families to single men in the region of 4 to 1 , so that future planning of garrison developments must recognise these factors and a higher degree of priority be given to the provision of amenities to satisfy the social needs of the married family communities.

\section{Families morbidity B.A.O.R.}

Although no published health statistics are available in U.K. regarding the attendance rates at medical centres of families in B.A.O.R., some figures are available in B.A.O.R. Taking a single division as an example. Table I gives the figures of average attendances at medical centres both families and troops for 1970:

It will be noted that there is firstly no drop in attendances in the summer months when troops could well be expected to be on leave. In fact the reverse is true as one of the highest months is July when medical officers are often on leave. Secondly an almost exact attendance ratio of families to troops of $2: 1$ is shown. In other words families medical care takes up twice as much time as soldiers medical care, the latter being the 
Table I

Average first attendances at medical centres

\begin{tabular}{l|c|c|c|c|c|c|c|c|c|c|c|c|c}
\hline & Jan & Feb & Mar & Apr & May & Jun & Jul & Aug & Sep & Oct & Nov & Dec & Total \\
\hline Troops & 3300 & 3000 & 2700 & 3400 & 2600 & 3200 & 3300 & 2800 & 2600 & 3100 & 3200 & 2900 & 36,000 \\
\hline Families & 6200 & 6000 & 6000 & 6100 & 5500 & 6300 & 7000 & 6000 & 6200 & 6100 & 6500 & 6200 & 74,100 \\
\hline
\end{tabular}

primary reason for the medical officer being in Germany. The attendance/domiciliary visit $(A: V)$ ratio is troops $100: 1$, families $11: 1$, so that the time-consuming part of the medical officer's work, the domiciliary visit, is heavily weighted towards families.

The AF W 3181 gives a broad breakdown of these total figures into 5 main groups of disease (Table II).

Table II

Breakdown of five main groups of diseases

\begin{tabular}{l|l|l}
\hline \multicolumn{1}{c|}{ Disease } & \multicolumn{1}{|c}{ Troops } & \multicolumn{1}{c}{ Families } \\
\cline { 2 - 3 } Respiratory & 6,700 & 17,000 \\
\hline Alimentary & 3,300 & 5,700 \\
\hline Skin & 5,000 & 5,800 \\
\hline Injuries & 9,400 & 3,600 \\
\hline All others & 12,400 (30 per cent) & 41,500 (57 per cent) \\
\hline
\end{tabular}

This breakdown is not precise in that it leaves 30 per cent unspecified so far as anyone further up the medical administrative chain is concerned and with families the position is even more vague in that nearly 60 per cent of the first attendances are so recorded. It must not be thought that these figures are total attendances as to these must be added the S.S.A.F.A. sister workload shown in Table III.

Table III

S.S.A.F.A. sister work load

\begin{tabular}{l|c|l|c}
\hline \multicolumn{1}{c|}{ Attendance at } & Numbers & \multicolumn{1}{|c|}{ Attendance at } & Numbers \\
\hline Home visits & 25,000 & Clinic visits & 35,000 \\
\hline Antenatal and postnatal & $5,000+$ & School health service & 9,000 \\
\hline
\end{tabular}

These figures suggest that the B.A.O.R. families minor morbidity pattern could well be different from their civilian counterpart as the average dependant there sees a medical officer 5 times a year, as against 3.5 in U.K. and 0.9 for Army dependants in 1938. 
Families morbidity Singapore

During period 1968/70 the Assistant Director of Medical Services office, Headquarters Singapore District found considerable difficulty in providing medical officers for troop exercises and detachments. The cause was found to be due to the work in families medical centres which was taking up a large proportion of the M.Os time, and it became increasingly obvious that, in fact, the families were producing the major part of the work load in the ratio families: troops $3: 2$.

It was not easy to determine the nature of the medical care given as although each medical centre made the usual monthly return on AF W 3181 which included dependants, the greater part of the minor morbidity consistently appeared under the heading 'All Other Diseases '. In effect this meant that only the medical officer who saw the patients was in possession of any information regarding the actual work being done in the medical centre. Fortunately at this time Captain Blackburn R.A.M.C., with a bent for general practice research, arrived. As he wished to carry out a major study on family morbidity, he was posted to the busiest family medical centre where he remained undisturbed for his entire tour. He produced an excellent paper (1971) which covered many facets of British families medical care in the Singapore environment and from which figures are now quoted.

Blackburn showed that during their first year abroad 93 per cent of the practice attended, as against a U.K. national figure ranging from 50 to 85 per cent, and this figure fell away the longer the family remained in the station within a normal tour. This would suggest that greater efforts should be made in the preparation of families for overseas tours and in assisting them to adjust to the altered environment by increased health education from Health Visitors/S.S.A.F.A. Sisters during the early part of their tours.

The average number of consultations/patient during the first year was 6.9 (Table IV) which compares with a U.K. national average of 3 to 4 , which once again fell away as the families became adjusted to Singapore. Careful record keeping also confirmed the suspicion that the greater number of consultations related to young children and young mothers. This information was not, of course, available from the standard AF W 3181.

Table IV

Average number of consultations/patient during the first year

\begin{tabular}{|c|c|c|c|c|c|}
\hline \multicolumn{6}{|c|}{ Mean annual consultation rate } \\
\hline Age (years) & Male & Female & Age (years) & Male & Female \\
\hline 0 to 4 & 7.7 & 8.5 & 20 to 29 & - & 10.6 \\
\hline 5 to 9 & 5.0 & 5.2 & 30 to 39 & - & 8.4 \\
\hline 10 to 19 & 3.4 & 4.7 & 40 plus & - & 6.9 \\
\hline
\end{tabular}

Note: There were no dependant males in the over 20 age group.

If we look at the attendance as they would have been presented on a standard AF W 3181, Table V shows that 40 per cent of the medical officer's work is undescribed. 
Table V

Attendances shown in disease group categories

\begin{tabular}{l|c|l|c}
\hline \multicolumn{1}{c|}{ Disease group } & Rate/1000 & Disease group & Rate/1000 \\
\hline Respiratory & 1916 & All other diseases & 2762 (40 per cent) \\
\hline Alimentary & 937 & Injuries & 359 \\
\hline Skin & 886 & Totals & 6860 \\
\hline
\end{tabular}

While Blackburn's work, Table VI shows how this indefinite 'All Other Diseases' group is in fact broken down.

Table VI

Breakdown of 'All Other Diseases' group

\begin{tabular}{|c|c|c|c|}
\hline \multicolumn{2}{|r|}{ Disease Group } & Rate $/ 1000$ & Per Cent Follow Up \\
\hline \multicolumn{2}{|c|}{ Respiratory system } & 1916 & 22 \\
\hline \multicolumn{2}{|c|}{ Digestive system } & 704 & 23 \\
\hline \multicolumn{2}{|c|}{ Skin and cellular tissue } & 886 & 19 \\
\hline \multirow{11}{*}{$\begin{array}{l}\text { All Other } \\
\text { Diseases }\end{array}$} & Infective and parasitic & 235 & 25 \\
\hline & Neoplasms & 5 & 40 \\
\hline & Allergic, endocrine and metabolic & 213 & 49 \\
\hline & Blood disorders & 41 & 49 \\
\hline & Mental and psycho-neurotic & 474 & 57 \\
\hline & Nervous system and sense organs & 778 & 32 \\
\hline & Circulatory system & 109 & 44 \\
\hline & Genito-urinary system & 504 & 42 \\
\hline & Complications of pregnancy & 96 & 33 \\
\hline & Bones and organs of movement & 198 & 45 \\
\hline & Symptoms, ill-defined, undiagnosed & 226 & 28 \\
\hline \multicolumn{2}{|l|}{ Accidents } & 359 & 14 \\
\hline \multicolumn{2}{|c|}{ Non-sickness } & 107 & 10 \\
\hline & & 6851 & \\
\hline
\end{tabular}

This table is obviously more useful and certain trends can now be detected which could be fed back into the training system, for example greater emphasis on genitourinary teaching perhaps as these cases present frequently and require considerable follow up. Again the high incidence of disease of sense organs-in fact otitis-is highlighted. 


\section{Family morbidity studies in B.A.O.R. and Hong Kong}

Fanning (1967) in a survey embracing 1608 (65 per cent) of the patients in his practice found a 57 per cent greater morbidity in flat dwellers compared to house occupants. This increased morbidity in the families of servicemen in B.A.O.R. was largely due to respiratory infections, particularly in young children and psycho-neurotic disorders in the wives.

The reasons for this increased morbidity has been fully documented by Hird (1966) as well as by Fanning (1967) and it is not intended to discuss this aspect in this paper.

Fanning's paper does give an idea of total workload for the whole practice during 1965 (Table VII) and morbidity by some disease groups (Table VIII).

Table VII

Total morbidity in one practice-B.A.O.R. 1965

\begin{tabular}{c|c|c}
\hline $\begin{array}{c}\text { Total patients } \\
\text { average } \\
\text { population }\end{array}$ & $\begin{array}{c}\text { Total consultations } \\
\text { with a general } \\
\text { practitioner }\end{array}$ & $\begin{array}{c}\text { No consultations } \\
\text { per patient } \\
\text { per annum }\end{array}$ \\
\hline 2,480 & 11,187 & 4.51 \\
\hline
\end{tabular}

Table VIII

Comparison of first attendance rates by general practitioners in flats and houses by selected disease groups

\begin{tabular}{|c|c|c|c|c|c|c|}
\hline Disease group & Patients & $\begin{array}{c}\text { First } \\
\text { attendances }\end{array}$ & $\begin{array}{c}\text { Rates } \\
\text { per } 1000\end{array}$ & Patients & $\begin{array}{c}\text { First } \\
\text { attendances }\end{array}$ & $\begin{array}{c}\text { Rates } \\
\text { per } 1000\end{array}$ \\
\hline $\begin{array}{l}\text { Respiratory } \\
\text { system }\end{array}$ & 227 & 244 & 209.8 & 38 & 45 & 101.1 \\
\hline Digestive system & 77 & 77 & 66.2 & 27 & 27 & 60.7 \\
\hline $\begin{array}{l}\text { Mental and } \\
\text { psycho-neurotic }\end{array}$ & 42 & 42 & 36.1 & 8 & 8 & 17.9 \\
\hline $\begin{array}{l}\text { Bones and organs } \\
\text { of movement }\end{array}$ & 11 & 11 & 9.5 & 11 & 11 & 24.7 \\
\hline Genito-urinary & 61 & 61 & 52.5 & 10 & 10 & 22.5 \\
\hline Accidents & 26 & 26 & 22.4 & 16 & 16 & 35.9 \\
\hline Indiagnosed & 65 & 71 & 61.0 & 12 & 13 & 29.2 \\
\hline Non-sickness & 28 & 28 & 24.1 & 10 & 10 & 22.5 \\
\hline
\end{tabular}

Of particular interest in Table VII is the average annual consultation rate per patient 4.51 compared with other surveys e.g. 2.2 in Hong Kong (1968). In Table VIII also note the workloads shown by the disease groups labelled Undiagnosed and Nonsickness.

Power (1970) carried out a pilot survey of sickness in service families in Hong Kong, all living in flats. Total morbidity is shown in Table IX and it is of interest to note the lower attendance rate compared with B.A.O.R. Also in Table $X$ are shown differences 
in morbidity related to different geographical locations. The next step was to select the two groups of flat dwellers with the highest and lowest morbidity respectively as shown in Table XI. Although the total number of patients is too small to attribute real statistical significance the marked difference in respiratory diseases is noteworthy and to a lesser extent there are differences in skin and digestive complaints which favour the Tai Hang Road patients.

Table IX

First attendance morbidity in a selected population of flat dwellers March/May 1968-Hong Kong

\begin{tabular}{c|c|c|c}
\hline Patients & Families & $\begin{array}{c}\text { First consultation with general } \\
\text { practitioner in a 3 month period }\end{array}$ & $\begin{array}{c}\text { Consultations per patient } \\
\text { equivalent annual rate }\end{array}$ \\
\hline 1375 & 442 & 737 & 2.2 \\
\hline
\end{tabular}

Table X

First attendances in flat dwellers by geographical location March/May 1968-Hong Kong

\begin{tabular}{l|c|c|c|c}
\hline \multicolumn{1}{c|}{ Location } & Patients & Families & $\begin{array}{c}\text { First consultations in a } \\
\text { 3 month period }\end{array}$ & $\begin{array}{c}\text { Rate per } \\
1000\end{array}$ \\
\hline Stanley Bay & 2370 & 66 & 138 & 600.0 \\
\hline Lye Mun & 70 & 29 & 89 & 1271.4 \\
\hline Blue Pool Road & 90 & 28 & 51 & 566.7 \\
\hline Tai Hang Road & 105 & 36 & 27 & 257.1 \\
\hline Boundary Street & 431 & 133 & 228 & 529.0 \\
\hline Vista Panorama & 103 & 30 & 49 & 457.7 \\
\hline Kowloon Tsai & 346 & 120 & 155 & 448.0 \\
\hline
\end{tabular}

Table XI

First attendances by some disease groups. Flat dwellers in Lye Mur compared with those in Tai Hang Road-Hong Kong 1968

\begin{tabular}{l|c|c|c||c|c|c}
\hline \multicolumn{1}{|c|}{ Disease group } & Patients & $\begin{array}{c}\text { First } \\
\text { consultations }\end{array}$ & $\begin{array}{c}\text { Rate } \\
\text { per } \\
1000\end{array}$ & Patients & $\begin{array}{c}\text { First } \\
\text { consultations }\end{array}$ & $\begin{array}{c}\text { Rate } \\
\text { per } \\
1000\end{array}$ \\
\hline Respiratory & 38 & 41 & 585.7 & 1 & 9 & 85.7 \\
\hline Skin diseases & 11 & 11 & 155.5 & 5 & 5 & 47.6 \\
\hline Digestive system & 10 & 11 & 155.5 & 3 & 3 & 28.6 \\
\hline $\begin{array}{c}\text { Mental and } \\
\text { psycho-neurotic }\end{array}$ & 3 & 3 & 42.8 & 2 & 2 & 19.0 \\
\hline Accidents & 1 & 1 & 14.3 & 1 & 1 & 9.5 \\
\hline
\end{tabular}

Power (1970), in his investigations into the physical environment, found that the differences in the flats themselves were insufficient to account for variations in morbidity. 
It was clear that more general social and physical factors were at work. To try to get some insight into these aspects he sent a team of investigators into every flat and the families therein recorded their answers to a selected set of questions on a proforma.

Some of the differences between the Lye Mun and the Tai Hang Road flat dwellers are shown in Table XII. These differences may reflect such facts as differences in sex and age groups i.e. Tai Hang Road families had twice as many female children in the younger age groups. They were also the rather older, more experienced wives of senior soldiers who might be expected to look after themselves and their children better than the Lye Mun families. On the other hand the latter saved more money, employed more domestic helps and used the local taxi service more. Would this indicate a better quality of life generally or the reverse e.g. if saving money are they spending sufficient on good quality food and so maintain adequate nutrition especially in children?

Table XII

Attitude and habit survey-Lye Mun and Tai Hang Road Families-Hong Kong 1968

\begin{tabular}{|c|c|c|c|}
\hline Factor & $\begin{array}{l}\text { Lye mun } \\
\text { families } \\
\text { per cent }\end{array}$ & $\begin{array}{l}\text { Tai Hang Road } \\
\text { families } \\
\text { per cent }\end{array}$ & Remarks \\
\hline $\begin{array}{l}\text { Problems and/or } \\
\text { complaints }\end{array}$ & 82 & 70 & $\begin{array}{l}\text { Young wives-less self reliant } \\
\text { and less experienced. }\end{array}$ \\
\hline Regular money savers & 96 & 37 & $\begin{array}{l}\text { Young wives-less adventurous, } \\
\text { do not go out much. }\end{array}$ \\
\hline $\begin{array}{l}\text { Domestic help employed } \\
\text { full time }\end{array}$ & 36 & NIL & $\begin{array}{l}\text { Young wives use domestic help } \\
\text { because? less experienced with } \\
\text { housework and children. }\end{array}$ \\
\hline Used own car regularly & 18 & 13 & \\
\hline $\begin{array}{l}\text { Used taxis regularly } \\
\text { Used mainly public } \\
\text { transport }\end{array}$ & $\begin{array}{l}50 \\
32\end{array}$ & $\left.\begin{array}{l}20 \\
67\end{array}\right\}$ & $\begin{array}{l}\text { Young wives less likely to to } \\
\text { venture into public transport } \\
\text { with language difficulties and } \\
\text { an alien population. }\end{array}$ \\
\hline
\end{tabular}

\section{Discussion}

When between one third and one half of the diseases recorded on the monthly morbidity form (AF W 3181) and some two-thirds on the monthly admissions to hospital (AF W 3166) are shown under 'All Other Diseases', it is apparent that a more detailed breakdown of these forms is required. If also medical attendance for, and admission to hospital of, dependants now contributes two-thirds of a medical officer's work, as for instance in B.A.O.R., then the training for and organisation of primary medical care will have markedly altered.

Fanning (1967) and Power (1970) surveys, as adjuncts to statistical analysis of morbidity, are very useful tools in trying to determine the exact causes of increased morbidity and the reasons for differences in separate groups of families. Finally, another and perhaps the most useful tool of all is to study in detail the breakdown of the "All Other Diseases' group as described by Blackburn (1971) of his work in Singapore, and 
then try to relate these differences by sex and age group to variations in the social, economic and general physical and psychological environment.

\section{REFERENCES}

Army Works Study Group (1968). Guided Project No. 95. Multi Medical Centres. H.M.S.O. London. Blackburn, R. (1971). J. Coll. gen. Practit. 21, 168.

CoRMACK, J. D. (1970). J. roy. Army med. Cps. 116, 220.

Crombie, D. L. (1964). J. roy. Army med. Cps. 110, 197.

Editorial (1970). J. roy. Army med. Cps. 116, 2.

FANNING, D. M. (1967). Brit. med. J. iv, 382.

FRY, J. (1964). J. roy. Army med. Cps. 110, 187.

HIRD, J. F. B. (1966). J. Coll. gen. Practit. Suppl. No. 1, 33.

Power, J. G. P. (1970). Community Hlth. 1, 316.

\section{ACADEMIC ACHIEVEMENTS}

F.R.C.P.(Ed.)

BRIGAdIER R. M. VANREENEN, M.B., M.R.C.P.(Ed.), M.R.C.Path., D.T.M.\&H., Late R.A.M.C. COLONEL J. F. WEBB, M.C., M.D., M.R.C.P.(Ed.), Late R.A.M.C. LifUTENANTCOLONEL I. C. CRAWFORD, M.B., Ch.B., M.R.C.P.(Ed.), R.A.M.C.

F.R.C.Psych. $\quad$ MAJOR-GENERAL J. MCGHIE, Q.H.P., M.D., D.P.M., Late R.A.M.C. BRIGADIER J. F. D. MURPHY, M.D., D.P.M., Late R.A.M.C.

F.R.C. Path.

BRIGADIER R. M. VANREENEN, M.B., F.R.C.P.(Ed.), M.R.C.Path., D.T.M.\&H., Late R.A.M.C.

M.R.C.G.P.

Major C. M. French, M.D., M.A., B.Chir,, D.T.M.\&H., R.A.M.C. Major H. C. MASON, M.B., Ch.B., R.A.M.C. MAJOR K. H. M. YOUNG, M.B., B.Ch., B.A.O., D.P.H., D.T.M.\&H., R.A.M.C.

F.F.R.

MAJOR J. H. WILLIAMS, M.B., Ch.B., D.M.R.D., D.T.M.\&H., R.A.M.C.

D.Obst.R.C.O.G. Captain J. K. Geraghty, M.A., M.B., B.ch., B.A.O., R.A.M.c. Captain A. M. GRIEVE, M.B., Ch.B., R.A.M.C.

D.C.H.

D.Phys.Med.

Captain M. W. Marshall, M.B., Ch.B., R.A.M.C.

Captain M. Blackman, M.B., B.Ch., B.A.O., R.A.M.C. Captain D. W. F. Glen, M.B., ch.B., R.A.M.c. Captain P. Melling, M.B., B.S., R.A.M.C. Captain I. D. Plant, M.B., Ch.B., R.A.M.C.

D.Av.Med.

MAJOR K. EDGINGTON, M.R.C.S., L.R.C.P., R.A.M.C. 